\title{
Comprehensive Study on Ethiopia Renewable Energy Technology Development and Barriers to Meet Rural Energy Needs
}

\author{
Ashebir Dingeto Hailu* \\ Department of Mechanical Engineering, Bule Hora University \\ PO box 144, Bule Hora, Ethiopia \\ Duba Cana Daro \\ Department of Water Resource and Irrigation Engineering, Bule Hora University \\ PO box 144, Bule Hora, Ethiopia
}

There is no any organization that made significant financial support for this work.

\section{Abstract}

Renewable energy has the potential to play a significant role in providing access to clean and affordable energy services to developing countries' vast populations. Ethiopia, a developing country in Sub-Saharan Africa, has an abundance of renewable energy resources that can meet the ambitions of both urban and rural energy demand. However, these resources are currently underutilized, and approximately 83 percent of the country's rural societies rely entirely on conventional biomass energy sources for cooking and lighting. As a result, this study examines, critically evaluates, and synthesizes the findings of the most recent Ethiopian studies on renewable energy technology, development, and barriers to meeting rural energy demand. In addition, this comprehensive study will update knowledge and information on the development of renewable energy technologies (RETs) to improve rural energy access. Furthermore, it aids in the promotion of RETs and the attraction of local and foreign actors to the development of renewable energy technology for lighting, water pumping, and agricultural development. Finally, the factors influencing a country's adoption of RETs are examined, and pragmatic recommendations are made.

Keywords: Ethiopia, Rural, Renewable energy technology, Small scale

DOI: $10.7176 /$ JETP/11-3-02

Publication date:June $30^{\text {th }} 2021$

\section{Introduction}

Access to clean, low-cost energy services is critical for societal socioeconomic development and life quality improvement (Guta et al., 2017). The increase in global population and economic activity will result in an increase in energy demand in the coming decades (Bouraiou et al., 2020). Globally, approximately 1.3 billion people, primarily in developing countries, lack access to electricity (Sieminski, 2013), They rely on traditional biomass fuels for cooking and heating, as well as kerosene for lighting.

More than 620 million people in Sub-Saharan Africa lack access to electricity, and nearly 730 million rely on unsafe and inefficient cooking methods. Meanwhile, those who do have access to modern energy may face exorbitant supply costs. Ethiopia, a country in Sub-Saharan Africa, has a diverse range of energy resources, including hydro, solar, wind, biomass, natural gas, geothermal, and so on. However, it is no longer capable of harnessing and utilizing these resources for the most beneficial economic development.

The majority of Ethiopians (more than 83 percent) live in rural areas. They are located far from the nearest utility grid system and continue to rely on biomass fuel for cooking, heating, and lighting, resulting in a high health burden ${ }^{[7]}$. Ethiopia currently generates only about 4.5GW (2019) of electric power, the majority of which is generated by hydro (90 percent) and the remainder by wind energy (7.6 percent) (Hailu \& Kumsa, 2021; Van de Graaf, 2014).

However, this capacity is insufficient in comparison to the country's vast energy resource potential. Many experts now agree that small scale off grid and mini-grid Renewable Energy Technologies (RETs) are economically viable and ideal for rural areas in order to achieve universal access to electricity supply (Martinot \& McDoom, 2000; Painuly, 2001). However, only a few considerations were given in the country to develop standalone and mini-grid electric supply, which was expected to be the alternative to solving the community's energy access problem. As a result, the goal of this study is to examine the currently available alternative energy technology advancement opportunities that could be used to meet rural energy needs while also boosting the country's socioeconomic development. Furthermore, this study provides useful information for the development of Renewable Energy Technologies (RETs) in rural Ethiopia.

\section{Literature Review on Renewable Energy Technology Development in Ethiopia}

In this section, recent articles on the barriers to household clean energy usage and the development of Renewable Energy Technology (RET) in rural Ethiopia are thoroughly reviewed, and the results and research contribution are systematically summarized in Table 1 . 
Table 1. Review of selected peer-reviewed publications on RET development in Ethiopia

\begin{tabular}{lll}
\hline Reference & Year & Review/contribution/ summary \\
\hline (Belay & Kassa, 2019 & The authors systematically reviewed current status, future potential and barriers \\
for renewable energy development in Ethiopia \\
Some barriers for the development of RET in Ethiopia were given as: \\
- & - Inadequate policy and regulation. \\
& - Lack of organized renewable energy resource data \\
& - Lack of local technical capacity \\
Some & Suggested solutions: \\
& - Enacting prudent and working policies. \\
& - Providing capacity building and skill gap training. \\
& - Providing forum and workshop to create awareness. \\
& - Creating local participation and ownership
\end{tabular}

(Guta, 2018) 2020 The author examined the determinants of household use of RETs in rural Ethiopia.

Some highlighted finding presented includes:

- A household wealth was increase the probability of household adoption of RETs.

- Poverty reduction policies would facilitate the use of RETs.

- Education will enhance awareness about the benefits of RETs.

(Gebreegziabher 2011 The authors investigated urban energy transition and technology adoption using et al., 2012) a dataset of 350 urban households in Tigrai, northern Ethiopia. The results of this paper have shows:

- Improvements in the level of education and income will likely enhance a household's use of electricity.

- Also call for forward for energy policy that can envision and respond to the growing demand for modern fuels.

(Kebede \& 2016 In this study Technological Innovation System (TIS) was conducted to address Mitsufuji, 2017) the challenges in development of RETs, case of solar PV systems the result shows that:

- It needs more effort from all actors to sustain solar PV market and address energy poverty of the nation.

- Policy intervention to articulate local participation.

- Building right skill through academic and research institutions.

(Mengistu et al., 2015 This paper reviews the dissemination status of household biogas technology, 2015) factors influencing the dissemination of the technology, benefits of the technology at global scales, energy resources, consumption patterns and brief account of the technology at national level in Ethiopia.

(Mondal et al., 2016 The author's presents the country power sector development and access and the 2017) result demonstrate:

- How different power generation technologies will be chosen to meet particular policy priorities.

- It shows that across all different policy scenarios, country energy supply need to diversify from hydropower to a mix of hydro, solar, and wind.

(Wassie \& 2020 The authors make analyses on the current utilization level, performance and Adaramola, 2020) impact of domestic biogas plants in rural Ethiopia and the main challenges observed are:

- The lack of maintenance and repair.

- Lack of focused biogas policy and regulation.

- Poor dissemination strategies.

- Lack of monitoring and follow - up.

- Lack of adequate technical support. 


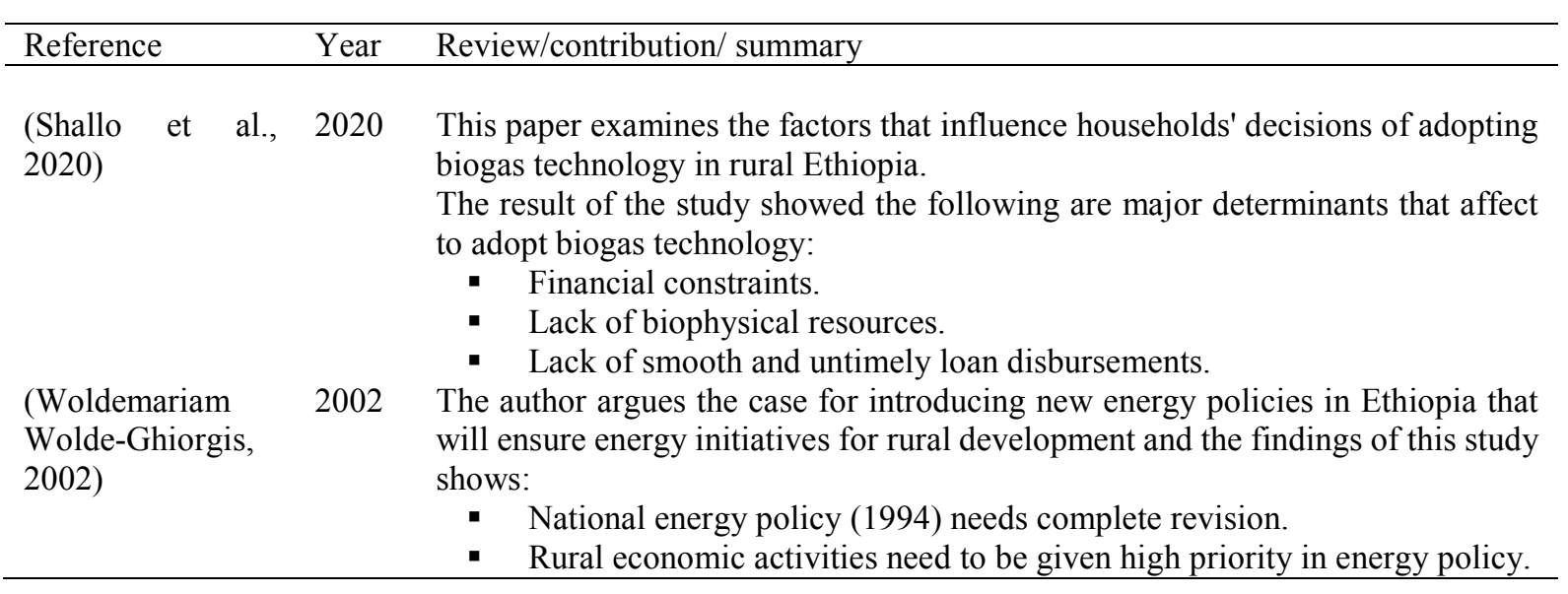

\section{Alternative Renewable Energy Technologies Relevant for Rural Electrification}

This section provides a brief discussion of currently available alternatives, Renewable Energy Technologies (RETs), to meet the energy demand of rural communities in Ethiopia, corresponding to the available Renewable Energy Resources (RERs). According to a World Bank report, most rural communities enjoy limited access to modern energy services due to issues of availability or affordability. As an alternative, they rely on conventional biomass fuels for the majority of their energy needs (Caufield, 1996). Such "energy poverty" has a significant impact on the community's living standards and productivity.

As a result, this section focuses on alternative technologies that can be used in Ethiopia, such as solar (thermal, photovoltaic, and cooker), wind energy (electricity generation and mechanical energy), biogas, and small hydroelectric plants, which are particularly suitable for meeting the basic energy needs of rural communities via standalone systems or off-grid electrification.

\subsection{Solar Energy Technologies}

Ethiopia, with a land area of approximately 1.097 million $\mathrm{km}^{2}$, is located in East Africa between $3^{\circ}$ and $15^{\circ} \mathrm{N}$ latitude and $33^{\circ}$ and $48^{\circ} \mathrm{E}$ longitude (Tucho et al., 2014). Because it is located in the tropics, the country receives a lot of solar energy, with irradiance ranging from $4.5 \mathrm{KWh} / \mathrm{m}^{2}$ to $7.5 \mathrm{KWh} / \mathrm{m}^{2}$ per day (Hailu \& Kumsa, 2021). Figure 1 illustrates the specifics of this potential. Ethiopia has a potential yearly solar radiation density of approximately $1992.2 \mathrm{kWh} / \mathrm{m}^{2}$ and a total energy reserve of 2,199,000.0 TWh (Kebede et al., 2015).

Sun energy has traditionally been used for drying and preserving agricultural products for many years. However, in recent years, photovoltaic cells have been used to harness solar energy for rural lighting, charging, water pumping, and street lighting (Soji-Adekunle et al., 2019). The majority of rural communities in Ethiopia live in dispersed rural villages, making the country an ideal location for using off-grid solar energy systems (Belay Kassa, 2019; Karekezi, 2002).

Despite its high technical potential, however, the country's solar power production remains limited, with only about $14 \mathrm{MW}$ of solar energy used for telecom service, lighting, powering water pumps in rural areas, and water heating in major cities (Senshaw, 2014). As a result, there are still significant opportunities to use the country's solar radiation potential simply by introducing efficient solar energy technologies to address the problem of rural energy access. The sections that follow elaborate on solar-energy-based RETs. 


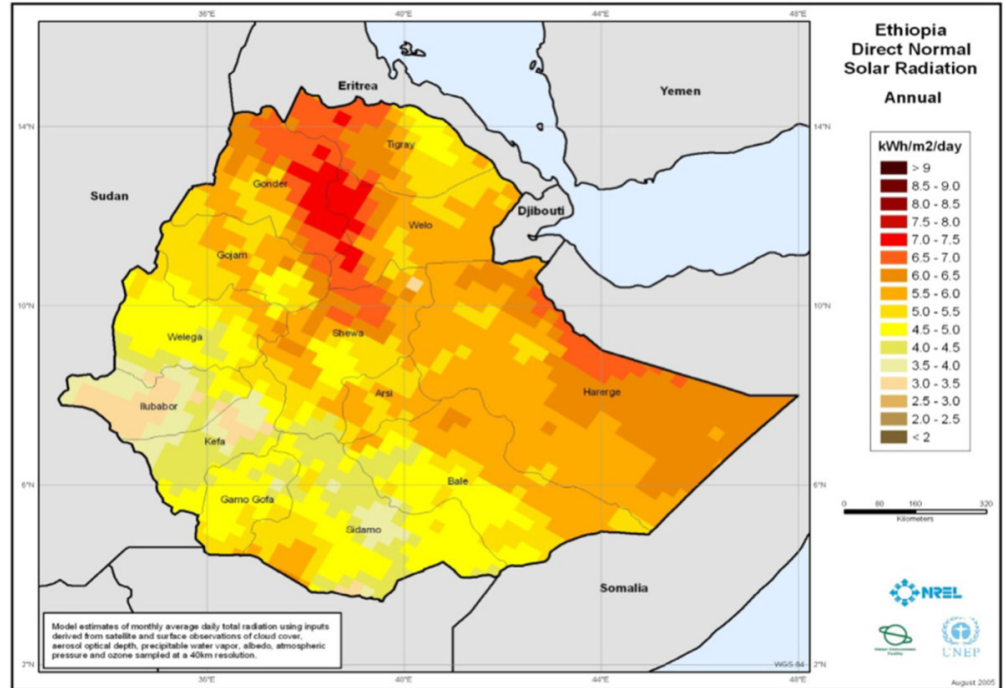

Figure 3. Ethiopia annual average daily total sum of DNI in $\mathrm{kWh} / \mathrm{m}^{2} /$ day (Kebede, 2015).

\subsubsection{Solar PV Technology}

Photovoltaic (PV) technology is now one of the most widely used solar energy collection technologies for supplying electric power to industrial systems and rural households. Photovoltaic technology, which directly converts solar radiation into electric energy using the photoelectric effect, has emerged as a better and more viable option for overcoming the global, energy, and environmental crises (Hartweg, 2017; Jean et al., 2015; Kannan \& Vakeesan, 2016; Li et al., 2017). Photovoltaic power generation systems can be used as off-grid or grid-connected systems, and the energy produced has been used to power telecom systems, hospitals, homes, street lighting, water pumping, and other applications (Choi \& Song, 2017).

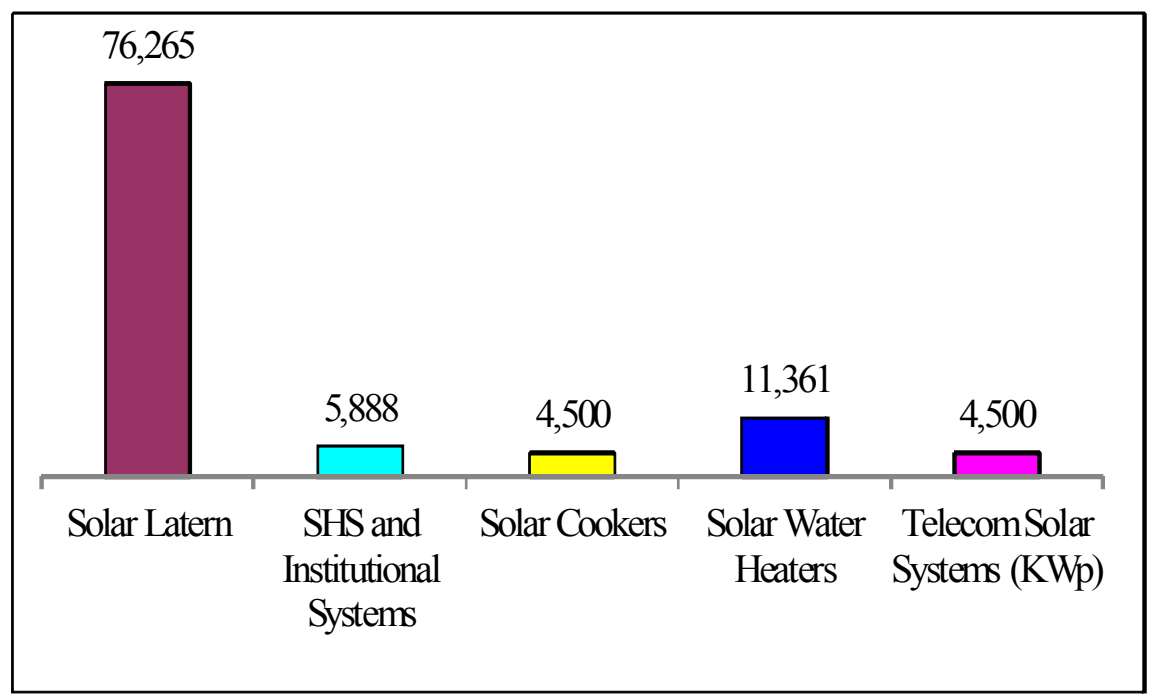

Figure 2. Number of solar energy technology in Ethiopia (Kebede \& Mitsufuji, 2017).

In Ethiopia, the first photovoltaic systems with a capacity of $10.5 \mathrm{kWp}$ were installed in mid-1985 for rural home lighting and school lighting (W Wolde-Ghiorgis, 1990). Solar PV technology is now being used in Ethiopia to light rural homes, health clinics, and schools, as well as to power telecom systems, solar water pumps, solar cookers, and solar water heating systems (Kebede, Mitsufuji, \& Choi, 2014). Figure 2 depicts the solar energy technology that was introduced in Ethiopia by 2011.

\subsubsection{Solar Thermal Technology}

The solar thermal collector is a type of solar thermal technology that converts sunlight into thermal energy. The reflector, absorber, and heat transportation media are the three main components of any solar thermal technology. Solar thermal collectors are divided into two types: concentrating collectors and non-concentrating collectors. Figure 3 depicts a general classification of solar collectors (Terrapon-Pfaff et al., 2014) and Table 2 gives their complete summary.

Unlike the photovoltaic process, solar thermal technology uses mirrors or lenses to concentrate a large area of sunlight into a small area to vaporize heat transferring fluids; the steam generated can then be used to drive 
turbines for power generation or to heat water in residential, process industries, and public buildings such as hotels, laundries, restaurants, hospitals, and health centers (Chu \& Meisen, 2011).

In Ethiopia, solar thermal systems are primarily comprised of simple, modular collectors with separate water tanks. Addis Ababa, Ethiopia's capital city, accounts for roughly $80 \%$ of total installed capacity of solar thermal technology. Existing growth and the estimated market potential for supplying hot water are realized through the use of solar thermal technology; however, in the absence of a favorable policy environment for the technology (Shanko, 2009). As a result, if favorable policy environments are created, along with increasing electricity tariff revisions, the total prospective market would be much larger.

Figure 3. Classification of solar collectors (Terrapon-Pfaff et al., 2014).

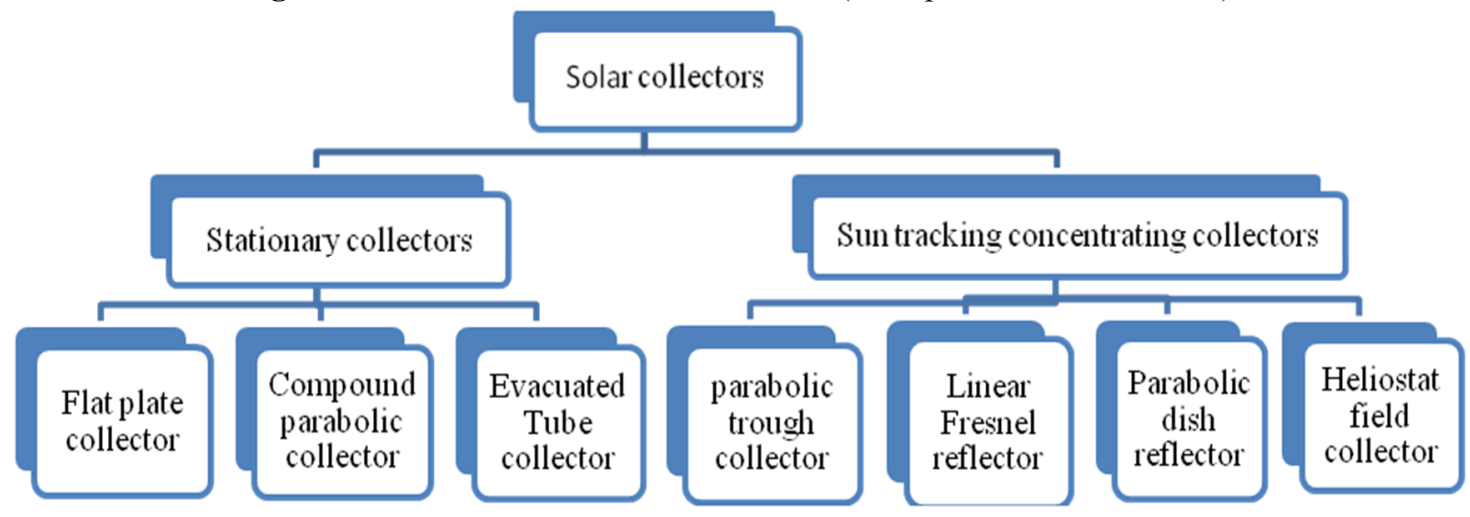

Table 2. Comprehensive summary of solar collectors (Kalogirou, 2013).

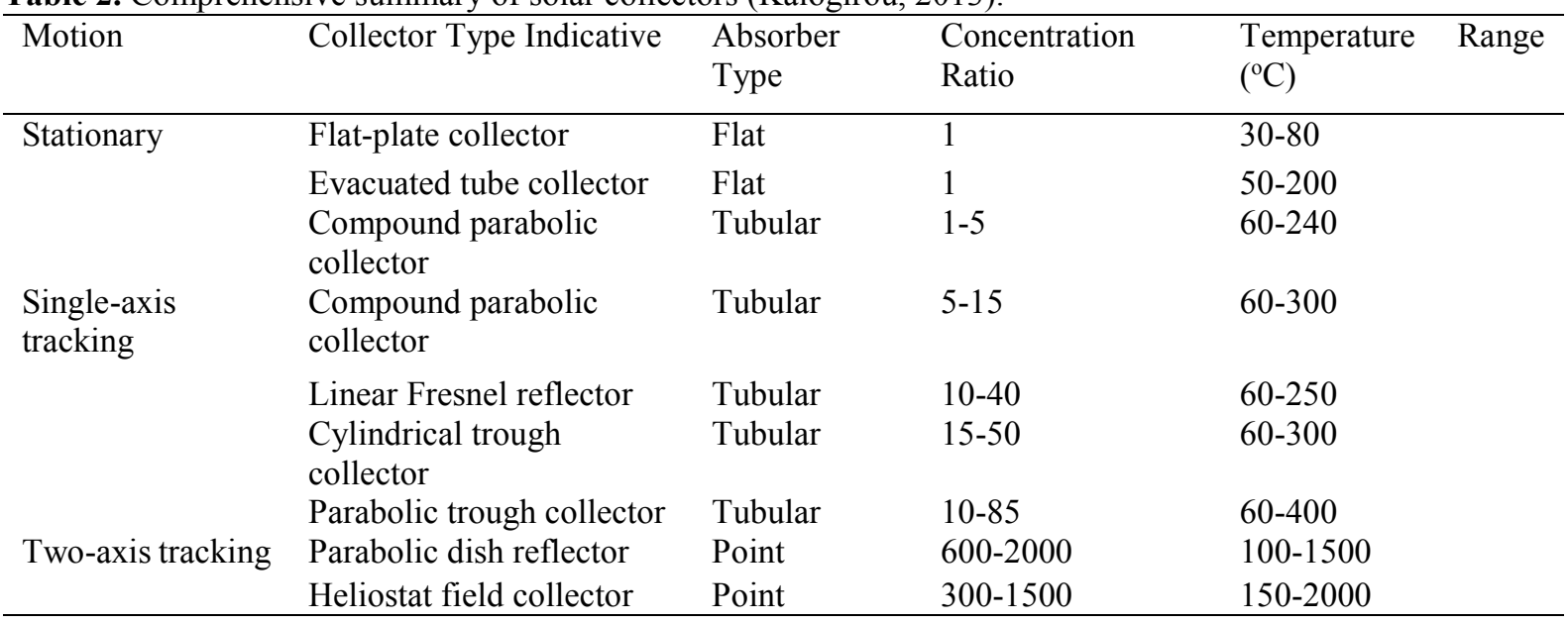

\subsubsection{Solar Cooker Technology}

According to the World Health Organization (WHO), 3 billion people cook with biomass and coal, resulting in 4 million deaths per year from household air pollution due to a lack of access to clean cooking technologies ((WHO), 2014).

In Ethiopia, 90 percent of the population relies on traditional biomass fuel for cooking, with 50 to 75 percent of energy used to bake Injera - traditional cake-like bread baked in a pan [37,38]. In most Ethiopian households, this Injera baking system is carried out using biomass fuel and an open fire system (Vaccari et al., 2017). Furthermore, such baking systems have drawbacks such as indoor air pollution, low efficiency, gender inequality, and high fuel consumption (Hassen et al., 2016). It is critical to introduce better cooking and heating technologies in order to improve health and general welfare. As a result, solar cooking technology is a better choice for reducing the health risks associated with indoor fire cooking as well as the financial burdens associated with firewood gathering or purchase. 


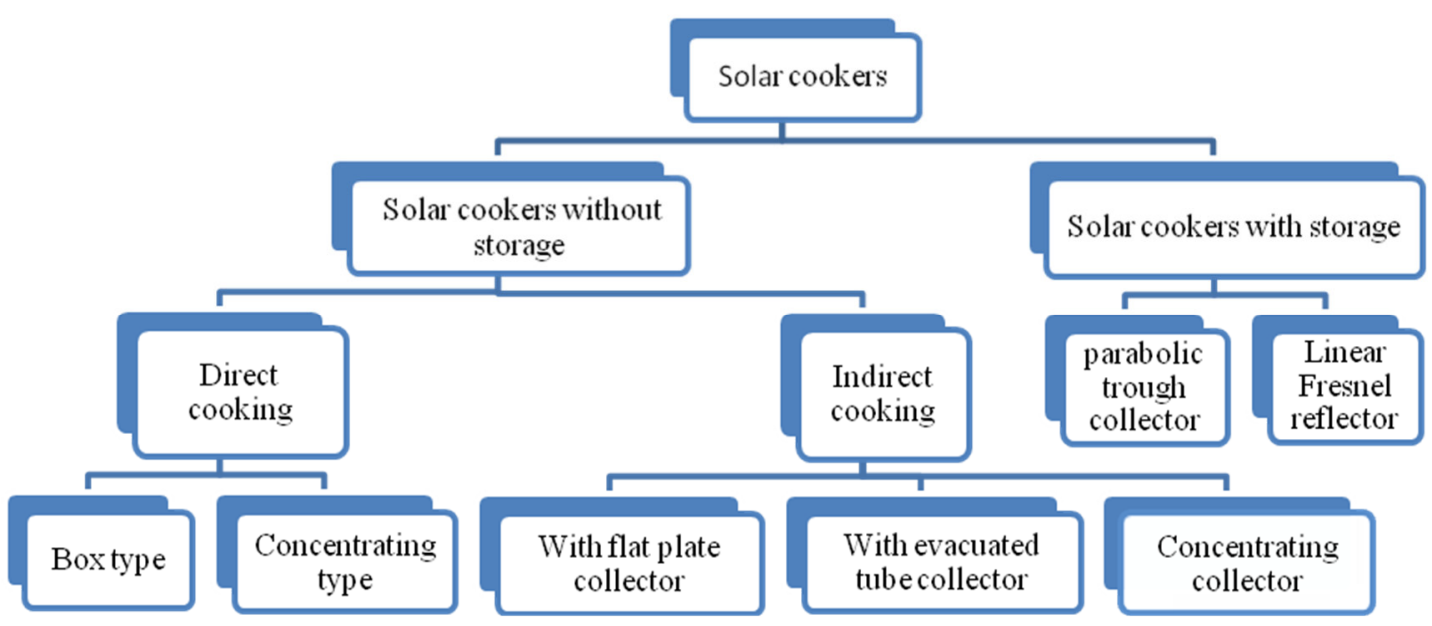

Figure 4. Classification of solar cookers (Muthusivagami et al., 2010).

Recently, solar energy has emerged as a potentially viable option for biomass fuel in food preparation(Tucker, 1999). Solar cookers of various types have been developed around the world. Nonetheless, as illustrated in Figure 4, we can roughly classify solar cookers into two categories. In comparison to solar PV technology, the implementation and utilization of solar cooker technology in Ethiopia is in its early stages, and the adoption and dissemination of solar cookers has been limited $[42,43]$. The majority of the research on solar cookers conducted in Ethiopia explained that the main reasons for the slow adoption of technology are poor integration between solar actors and financial issues (Kebede, Mitsufuji, \& Yemiru, 2014; Tesfay et al., 2014). As a result, additional research and development on solar cooker technology should be conducted, with integration to solar actors, in order to improve technology adoption and diffusion in the country's remote areas.

\subsection{Hydropower Technologies}

Hydropower technology harnesses the energy of falling water to generate electricity via water turbines and generators. The water turbine converts the potential energy of falling water into shaft power (Paish, 2002). The mechanical energy of a rotating shaft is then converted into electrical energy by an electric generator connected to the turbine. As a result, a change in the magnetic field flux causes current generation. Today, among other renewable resource utilization alternatives, this technology is the most widely used for electricity generation, and it is popular in both developing and developed countries (Peter \& Mbohwa, 2019).

Ethiopia is one of the Horn of Africa's developing countries, with approximately 14 hydropower dams with an average energy production capacity of $14,296.7 \mathrm{GWh} /$ year. Currently, hydropower generates the majority of Ethiopia's power generation capacity, accounting for approximately 85 percent $(3.8 \mathrm{GW})$ of the country's total energy production capacity, making it the primary energy source (Senshaw, 2014). Ethiopia is estimated to have 140 billion cubic meters of freshwater resources per year, with surface runoff water resources accounting for approximately 86 percent of this total. Ethiopia's terrain, in general, is favourable for hydropower projects. In Ethiopia, the presence of large rivers flowing through enormously carved valleys creates ideal conditions for mini to micro hydropower plants, with a total countrywide potential of approximately $45 \mathrm{GW}$ (van der Zwaan et al., 2018). Given the country's abundant water resource potential and the landscape's suitability for constructing multipurpose hydraulic infrastructures, developing this resource in various sizes (Pico, Micro, and mini, small, medium, and large scale) is a viable option for improving energy supply, irrigation development, and fish production. Table 3 shows the classification of Ethiopian hydropower systems as well as their capacity limits. Furthermore, building standalone Micro and Pico - hydropower electricity supply will be a better option for electrifying rural areas of the country.

Table 3. Ethiopia hydropower system classification on their capacity limits (Girma, 2016).

\begin{tabular}{lll}
\hline Classification & Capacity limits & Unit \\
\hline Large & $>30$ & MW \\
Medium & $10-30$ & MW \\
Small & $1-10$ & MW \\
Mini & $501-1,000$ & Kw \\
Micro & $11-500$ & Kw \\
Pico & $\leq 10$ & kW \\
\hline
\end{tabular}




\subsection{Wind Energy Technologies}

Wind power technology is one of the fastest growing renewable energy generation alternatives used globally. It can convert wind speed into usable energy by using wind turbines to power electrical generators or pumps and other machinery (Miketa et al., 2015).

Among the other energy technologies of the future, wind power is one of the most feasible and hopeful sources of energy. Due to significant advancements in turbine technology, the amount of energy generated by wind-driven turbines has increased exponentially in recent years, making wind energy cost-effective and competitive with fossil fuels (Aredom \& Amente, 2014).

Wind energy can be used to generate mechanical power by using windmills to lift surface and underground water for small-scale irrigation, domestic use, and livestock watering, or it can be used to generate electrical power by using wind turbines (Global, 2018; Salomonsson \& Thoresson, 2010).

The amount of electric energy produced by a wind turbine is determined by wind speed distribution, wind turbine selection, and wind turbine operational strategy and configuration. Wind turbines are made up of rotor blades, a drive shaft, a gearbox, a speed shaft, and a generator (Okundamiya et al., 2014).

Wind energy technology was introduced in Ethiopia in 1960, when more than 100 units of wind mills were built for water pumping applications, and approximately 70 of them are still operational today (Schubel \& Crossley, 2012).

According to the Ethiopian Ministry of Water, Irrigation, and Energy (MoWIE) report, Ethiopia has a 1,350 GW exploitable wind energy potential (Hailu \& Kumsa, 2021; Mazengia, 2010). According to SWERA's wind resource estimation, some towns with high wind speeds for power generation are Adwa, Mekele, Debre Birhan, Debre Markos, Addis Ababa, Bishoftu, and Adama (Howell, 2011). Wind regions with a wind density of $300 \mathrm{~W} / \mathrm{m}^{2}$ and a wind speed of $6.5 \mathrm{~m} / \mathrm{s}$ or higher are suitable for grid-based electricity production. Ayisha in eastern Ethiopia has excellent potential, with an average wind speed of more than 8 m/s (Fay, 2012; Hailu \& Kumsa, 2021).

Nonetheless, despite the remarkable potential of this energy system, the country only harnessed about $324 \mathrm{MW}$ of power from three wind farms (Ashegoda, Adama I, and Adama II), indicating that there is still a significant amount of resource potential to increase the country's energy production capacity. Furthermore, the country intends to build four large-scale wind energy power plants (Ayisha, Messobo, Assela, and Debre Birhan wind power plants) with a total capacity of 542MW (Hailu \& Kumsa, 2021).

However, in addition to the country's plan for large-scale wind farms to meet grid-based electrification, the Ethiopian government should prioritize off-grid rural household power supply by using only small wind turbines under $100 \mathrm{~kW}$ for lighting, telecommunication, or water pumping. Furthermore, small wind turbines in hybrid configurations with diesel generators, batteries, and photovoltaic systems are better options for remote electrification in off-grid locations where a connection to the utility grid is not available.

\subsection{Biogas Technologies}

Ethiopia is one of the countries with a high potential for biogas production. However, this potential has not yet been realized, and the majority of rural communities rely on traditional energy sources (fuel wood, agricultural residues, and charcoal), which are rapidly depleting, exacerbating the rural energy crisis (SNV, 2008). As a result, establishing a small-scale biogas plant is a better option for addressing the rural energy crisis.

Fixed dome, floating drum, and bag digester technology are the three main types of biogas digester technology used in third-world countries. Biogas technology has been used in Ethiopia since 1957, when it was introduced at Ambo University to generate energy for welding agricultural tools (Amigun et al., 2012; Rajendran et al., 2012).

The National Biogas Program of Ethiopia (NBPE) was established in 2008 with the goal of establishing a long-term, user-driven biogas sector in the country. The NBPE was implemented gradually from 2009 to 2013 , and then again from 2014 to 2017 . In the first phase, 8063 small fixed dome bio-digesters $\left(4-10 \mathrm{~m}^{3}\right)$ were installed. In the second phase, 12,071 fixed dome biogas digesters were constructed (Freeman \& Seppala, 2019; Shallo \& Sime, 2019). Fixed dome bio-digesters are an excellent choice for rural communities because they are less vulnerable to destruction, are simple to operate, and are inexpensive. Figure 5 depicts a diagram of a fixed dome digester along with a description of its operation. 


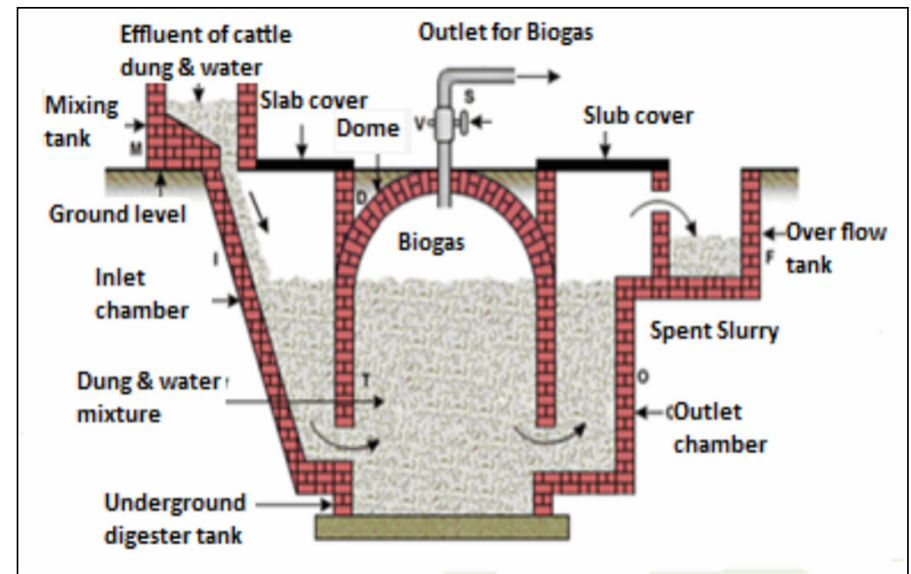

Figure 5. Schematic representation of a fixed-dome biogas plant (Kamp \& Forn, 2016).

However, there are still barriers to biogas technology's growth, dissemination, and long-term viability in rural areas (Wassie \& Adaramola, 2020). Policies and organizations, financial restrictions, incentives, availability of inputs, knowledge of the technology, market considerations, and success stories regarding biogas energy technology are the main obstacles to its expansion and use in rural areas.

As a result, the government should establish the necessary policy instruments and institutions, as well as loans and subsidies, to accelerate the spread of biogas energy technologies. Furthermore, appropriate government policies should be implemented to foster the dissemination of RETs, mobilize resources, and encourage the participation of private investors.

\section{Conclusions and Recommendations}

The majority of Ethiopians live in rural areas. They live a long way from the nearest utility grid link point and continue to rely on biomass fuels for cooking, heating, and lighting, putting a strain on their health. Despite substantial progress in expanding grid-based energy access for densely populated urban dwellers, the Ethiopian government has not provided off-grid rural energy access with the same level of attention. As a result, this study provides a comprehensive review of current RET developments as well as future work to provide remote areas with access to modern energy services. In addition, this paper conducted a literature review and highlighted the determinant factors influencing the development of RETs in rural Ethiopia. The study focuses on renewable energy technologies (RETs), which are better alternatives to meet rural energy needs, such as solar technology (thermal, photovoltaic, and cooker), wind energy technology (electricity generation and mechanical energy), small hydroelectric technology, and biogas technology. Ethiopia has an abundance of renewable energy resources such as hydropower, solar, wind, geothermal, biogas, and biomass energy to meet national energy demand and even leave some for foreign countries. However, the country lacks technological advancement and the ability to capitalize on it. As a result, it is suggested that:

- Ethiopia's government should prioritize and support research and development activities, as well as feasibility studies on the development of RETs.

- Enabling government policy is critical for encouraging the use of RETs in rural areas.

- Government assistance should be provided in the form of regulation, subsidization, import duties, and community outreach.

- Adequate installation, operation, and maintenance training, as well as learning and awareness-raising activities, should be provided to develop effective and sustainable RET use.

\section{Conflict of Interest}

The author declares that there is no conflict of interests regarding the publication of this study.

\section{References}

(WHO), W. H. O. (2014). Burden of disease from Household Air Pollution for 2012. Geneva: WHO.

Adem, K. D., \& Ambie, D. A. (2017). A review of injera baking technologies in Ethiopia: Challenges and gaps. Energy for Sustainable Development, 41, 69-80.

Amigun, B., Parawira, W., Musango, J. K., Aboyade, A. O., \& Badmos, A. S. (2012). Anaerobic biogas generation for rural area energy provision in Africa. Biogas, 36-62.

Aredom, M., \& Amente, G. (2014). Comparative Study on Wind Power using Meteorological Data and Wind Turbine Output at Ashogoda Village, Northern Ethiopia. East African Journal of Sciences, 8(1), 37-46.

Belay Kassa, A. (2019). Current Status, Future Potential and Barriers for Renewable Energy Development in 
Ethiopia. Iranian (Iranica) Journal of Energy \& Environment, 10(4), 269-274.

Beyene, G. E., Kumie, A., Edwards, R., \& Troncoso, K. (2018). Opportunities for transition to clean household energy in Ethiopia: application of the household energy assessment rapid tool (HEART).

Bouraiou, A., Necaibia, A., Boutasseta, N., Mekhilef, S., Dabou, R., Ziane, A., Sahouane, N., Attoui, I., Mostefaoui, M., \& Touaba, O. (2020). Status of renewable energy potential and utilization in Algeria. Journal of Cleaner Production, 246, 119011.

Caufield, C. (1996). Masters of illusion: the World Bank and the poverty of nations. Henry Holt.

Choi, Y., \& Song, J. (2017). Review of photovoltaic and wind power systems utilized in the mining industry. Renewable and Sustainable Energy Reviews, 75, 1386-1391.

Chu, Y., \& Meisen, P. (2011). Review and comparison of different solar energy technologies. Global Energy Network Institute (GENI), San Diego, CA.

Cozzi, L., \& Gould, T. (2015). World Energy Outlook 2015. International Energy Agency.

Fay, M. (2012). Inclusive green growth: The pathway to sustainable development. World Bank Publications.

Freeman, K. K., \& Seppala, J. A. K. (2019). The Power of Dung: Lessons Learned from On-Farm Biodigester Programs in Africa. The World Bank.

Gebreegziabher, Z., Mekonnen, A., Kassie, M., \& Köhlin, G. (2012). Urban energy transition and technology adoption: The case of Tigrai, northern Ethiopia. Energy Economics, 34(2), 410-418.

Girma, Z. (2016). Techno-economic feasibility of small scale hydropower in Ethiopia: The case of the kulfo River, in Southern Ethiopia. Journal of Renewable Energy, 2016.

Global, I. (2018). Energy transformation: a roadmap to 2050.

Guta, D. D. (2018). Determinants of household adoption of solar energy technology in rural Ethiopia. Journal of Cleaner Production, 204, 193-204.

Guta, D. D., Jara, J., Adhikari, N. P., Chen, Q., Gaur, V., \& Mirzabaev, A. (2017). Assessment of the successes and failures of decentralized energy solutions and implications for the water-energy-food security nexus: Case studies from developing countries. Resources, 6(3), 24.

Hailu, A. D., \& Kumsa, D. K. (2021). Ethiopia renewable energy potentials and current state [J]. AIMS Energy, 9(1), 1-14.

Hartweg, B. (2017). Global implementation of renewable energy. In Climate Change Literacy and Education Social Justice, Energy, Economics, and the Paris Agreement Volume 2 (pp. 81-90). ACS Publications.

Hassen, A. A., Kebede, S. B., \& Wihib, N. M. (2016). Design and manufacturing of thermal energy based Injera baking glass pan. Energy Procedia, 93, 154-159.

Howell, J. (2011). Rural electrification and renewable energy in Ethiopia. Environmental Policy Group, Environmental Studies Program, Colby College, Waterville, Maine.

Jean, J., Brown, P. R., Jaffe, R. L., Buonassisi, T., \& Bulović, V. (2015). Pathways for solar photovoltaics. Energy \& Environmental Science, 8(4), 1200-1219.

Kalogirou, S. A. (2013). Solar energy engineering: processes and systems. Academic Press.

Kamp, L. M., \& Forn, E. B. (2016). Ethiopia' s emerging domestic biogas sector: Current status, bottlenecks and drivers. Renewable and Sustainable Energy Reviews, 60, 475-488.

Kannan, N., \& Vakeesan, D. (2016). Solar energy for future world:-A review. Renewable and Sustainable Energy Reviews, 62, 1092-1105.

Karekezi, S. (2002). Poverty and energy in Africa - a brief review. Energy Policy, 30(11-12), 915-919.

Karekezi, S., \& Kithyoma, W. (2002). Renewable energy strategies for rural Africa: is a PV-led renewable energy strategy the right approach for providing modern energy to the rural poor of sub-Saharan Africa? Energy Policy, 30(11-12), 1071-1086.

Kebede, K. Y. (2015). Viability study of grid-connected solar PV system in Ethiopia. Sustainable Energy Technologies and Assessments, 10, 63-70.

Kebede, K. Y., \& Mitsufuji, T. (2017). Technological innovation system building for diffusion of renewable energy technology: A case of solar PV systems in Ethiopia. Technological Forecasting and Social Change, $114,242-253$.

Kebede, K. Y., Mitsufuji, T., \& Choi, E. K. (2014). Looking for innovation system builders: A case of Solar Energy Foundation in Ethiopia. African Journal of Science, Technology, Innovation and Development, 6(4), 289300 .

Kebede, K. Y., Mitsufuji, T., \& Islam, M. T. (2015). Building Innovation System for the Diffusion of Renewable EnergyTechnology: Practices in Ethiopia and Bangladesh. Procedia Environmental Sciences, 28, 11-20.

Kebede, K. Y., Mitsufuji, T., \& Yemiru, B. S. (2014). Diffusion of solar cookers in Africa: status and prospects. International Journal of Energy Technology and Policy, 10(3-4), 200-220.

Li, G., Jin, Y., Akram, M. W., \& Chen, X. (2017). Research and current status of the solar photovoltaic water pumping system-A review. Renewable and Sustainable Energy Reviews, 79, 440-458.

Martinot, E., \& McDoom, O. (2000). Promoting energy efficiency and renewable energy: GEF climate change 
projects and impacts. Washington, DC: Global Environment Facility.

Mazengia, D. H. (2010). Ethiopian Energy Systems: Potentials, Opportunities and Sustainable Utilization.

Mengistu, M. G., Simane, B., Eshete, G., \& Workneh, T. S. (2015). A review on biogas technology and its contributions to sustainable rural livelihood in Ethiopia. Renewable and Sustainable Energy Reviews, 48, 306-316.

Miketa, A., Saygin, D., Ferroukhi, R. G., Hawila, D., Kojakovic, A., \& Nagpal, N. (2015). Africa 2030: Roadmap for a renewable energy future. Abu Dhabi.

Mondal, M. A. H., Bryan, E., Ringler, C., \& Rosegrant, M. (2017). Ethiopian power sector development: Renewable based universal electricity access and export strategies. Renewable and Sustainable Energy Reviews, 75, 11-20.

Muthusivagami, R. M., Velraj, R., \& Sethumadhavan, R. (2010). Solar cookers with and without thermal storagea review. Renewable and Sustainable Energy Reviews, 14(2), 691-701.

Okundamiya, M. S., Emagbetere, J. O., \& Ogujor, E. A. (2014). Assessment of renewable energy technology and a case of sustainable energy in mobile telecommunication sector. The Scientific World Journal, 2014.

Painuly, J. P. (2001). Barriers to renewable energy penetration; a framework for analysis. Renewable Energy, 24(1), $73-89$.

Paish, O. (2002). Small hydro power: technology and current status. Renewable and Sustainable Energy Reviews, $6(6), 537-556$.

Peter, O., \& Mbohwa, C. (2019). Renewable Energy Technologies In Brief. Int. J. Sci. Technol. Res.

Rajendran, K., Aslanzadeh, S., \& Taherzadeh, M. J. (2012). Household biogas digesters-A review. Energies, 5(8), 2911-2942.

Salomonsson, S., \& Thoresson, H. (2010). Windmill driven water pump for small-scale irrigation and domestic use: In Lake Victoria basin.

Schubel, P. J., \& Crossley, R. J. (2012). Wind turbine blade design. Energies, 5(9), 3425-3449.

Senshaw, D. A. (2014). Modeling and analysis of long-term energy scenarios for sustainable strategies of Ethiopia.

Shallo, L., Ayele, M., \& Sime, G. (2020). Determinants of biogas technology adoption in southern Ethiopia. Energy, Sustainability and Society, 10(1), 1-13.

Shallo, L., \& Sime, G. (2019). Determinants of functional status of family size bio-digesters: empirical evidence from southern Ethiopia. International Journal of Sustainable Energy, 38(5), 493-510.

Shanko, M. (2009). Ethiopia's bioenergy market, target market analysis. Deutsche Gesellschaft Für Technische Zusammenarbeit (GTZ) GmbH.

Sieminski, A. (2013). International energy outlook 2013. US Energy Information Administration (EIA) Report Number: DOE/EIA-0484.

SNV, E. \&. (2008). Ethiopian Rural Energy Development and Promotion Center (EREDPC) and Netherlands Development Organization (SNV). National Biogas Pro-Gramme Ethiopia: Programme Implementation Document.

Soji-Adekunle, A. R., Asere, A. A., Ishola, N. B., Oloko-Oba, I. M., \& Betiku, E. (2019). Modelling of synthesis of waste cooking oil methyl esters by artificial neural network and response surface methodology. International Journal of Ambient Energy, 40(7), 716-725.

Terrapon-Pfaff, J., Dienst, C., König, J., \& Ortiz, W. (2014). How effective are small-scale energy interventions in developing countries? Results from a post-evaluation on project-level. Applied Energy, 135, 809-814.

Tesfay, A. H., Kahsay, M. B., \& Nydal, O. J. (2014). Solar Powered Heat Storage for Injera Baking.

Tucho, G. T., Weesie, P. D. M., \& Nonhebel, S. (2014). Assessment of renewable energy resources potential for large scale and standalone applications in Ethiopia. Renewable and Sustainable Energy Reviews, 40, 422431.

Tucker, M. (1999). Can solar cooking save the forests? Ecological Economics, 31(1), 77-89.

Vaccari, M., Vitali, F., \& Tudor, T. (2017). Multi-criteria assessment of the appropriateness of a cooking technology: A case study of the Logone Valley. Energy Policy, 109, 66-75.

Van de Graaf, T. (2014). International Energy Agency. In Handbook of Governance and Security. Edward Elgar Publishing.

van der Zwaan, B., Boccalon, A., \& Dalla Longa, F. (2018). Prospects for hydropower in Ethiopia: An energywater nexus analysis. Energy Strategy Reviews, 19, 19-30.

Wassie, Y. T., \& Adaramola, M. S. (2020). Analysing household biogas utilization and impact in rural Ethiopia: Lessons and policy implications for sub-Saharan Africa. Scientific African, 9, e00474.

Wolde-Ghiorgis, W. (1990). An appraisal of the performance of a $10.5 \mathrm{~kW}$ SAPVS at a village in Ethiopia. Solar \& Wind Technology, 7(6), 725-734.

Wolde-Ghiorgis, Woldemariam. (2002). Renewable energy for rural development in Ethiopia: the case for new energy policies and institutional reform. Energy Policy, 30(11-12), 1095-1105. 